\title{
Species richness and geographic distribution of the genera Chydorus and Pseudochydorus (Cladocera, Chydoridae) in São Paulo State
}

\author{
Maria José Santos-Wisniewski, ${ }^{1,5}$ Odete Rocha ${ }^{2}$; Adriana Maria Guntzel ${ }^{3}$;akako Matsumura-Tundisi ${ }^{4}$ \\ ${ }^{1}$ Departamento de Ciências Biológicas, Universidade Federal de Alfenas - UNIFAL-MG, \\ Rua Gabriel Monteiro da Silva, 713, CEP 37130-000, Alfenas, MG \\ ${ }^{2}$ Universidade Federal de São Carlos - UFSCar, Centro de Ciências Biológicas e da Saúde, \\ Departamento de Ecologia e Biologia Evolutiva - DEBE, Rodovia Washington Luis, Km 235, Monjolinho, \\ CP 676, CEP 13565-905, Sao Carlos, SP, Brazil \\ ${ }^{3}$ Universidade Estadual de Mato Grosso do Sul - UEMS, \\ Rua Pereira Gomes, 355, Vila Santa Maria, CEP 79400-000, Coxim, MS, Brazil \\ ${ }^{4}$ Instituto Internacional de Ecologia - IIE, \\ Rua Bento Carlos, $n^{\circ}$ 750, Centro, CEP 13560-660, São Carlos, SP, Brazil \\ ${ }^{5}$ Corresponding author: Maria José Santos-Wisniewski,e-mail: mjw@unifal-mg.edu.br
}

Santos-Wisniewski, M. J.; Rocha, O.; Guntzel, A. M.; Matsumura-Tundisi, T. Species richness and geographic distribution of the genera Chydorus and Pseudochydorus (Anomopoda, Chydoridae) in São Paulo State. Biota Neotrop., vol. 8, no. 1, Jan./Mar. 2008. Available from: <http://www.biotaneotropica.org.br/v8n1/en/abst ract?article+bn01308012008>.

\begin{abstract}
The Chydorus and Pseudochydorus genera are widely distributed around the world. Some species of Chydorus are among the commonest anomopods and Pseudochydorus globosus, the only species of the genus, is believed cosmopolitan. This study was part of the project "Zooplanktonic biodiversity and state of degradation of continental water ecosystems in São Paulo State", itself a part of the FAPESP/BIOTA Program - The Virtual Institute of Biodiversity (www.biotasp.org.br), the aim being to make an inventory and analyze the distribution of species of the genera Chydorus and Pseudochydorus in São Paulo State, Brazil. In total, 373 samples were collected from 223 water bodies in the Water Resources Management Units of São Paulo State, between 9/9/1999 and $8 / 28 / 2002$. The sampled sites varied from small streams, rivers, ponds, lakes up to big reservoirs. Six species of the genus Chydorus and one of the genus Pseudochydorus were recorded. The most common and widely distributed species were Chydorus eurynotus and Chydorus pubescens. The species Chydorus parvireticulatus occurred only in one Water Resources Management Unit of the state, and constituted the first recorded of this species in São Paulo State.
\end{abstract}

Keywords: Anomopoda, Chydoridae, Littoral region, biodiversity.

Santos-Wisniewski, M. J.; Rocha, O.; Guntzel, A. M.; Matsumura-Tundisi, T. Distribuição das espécies dos gêneros Chydorus e Pseudochydorus (Cladocera, Chydoridae) no estado de São Paulo. Biota Neotrop., vol. 8, no. 1, jan./mar. 2008. Disponível em: <http://www.biotaneotropica.org.br/v8n1/pt/abstract?article+bn01 308012008>.

Resumo: Os gêneros Chydorus e Pseudochydorus são de ampla distribuição geográfica. Algumas espécies de Chydorus estão entre os anomópodos mais comuns e Pseudochydorus globosus, a única espécie do gênero, é considerada cosmopolita. O presente estudo está inserido no projeto "Biodiversidade zooplanctônica e o estado de degradação dos ecossistemas aquáticos continentais do estado de São Paulo", como parte do Programa BIOTA/FAPESP - O Instituto Virtual da Biodiversidade (www.biota.org.br) e teve como objetivo o inventário e a análise da distribuição das espécies dos gêneros Chydorus e Pseudochydorus no estado de São Paulo. Foram amostrados 223 corpos de água e 373 amostras das unidades de gerenciamento dos recursos hídricos do estado de São Paulo, entre 09/09/1999 e 28/08/2002. Os ambientes amostrados compreenderam desde pequenos córregos, rios, lagoas, lagos, até grandes reservatórios. Foram registradas seis espécies do gênero Chydorus e uma espécie do gênero Pseudochydorus. As espécies mais comuns e mais amplamente distribuídas foram Chydorus eurynotus e Chydorus pubescens. A espécie Chydorus parvireticulatus ocorreu em apenas uma unidade de gerenciamento recursos hídricos e constituiu o primeiro registro desta espécie no Estado de São Paulo.

Palavras-chave: Anomópodos, região litorânea, biodiversidade. 


\section{Introduction}

Research on the abundance and composition of the family Chydoridae in the littoral zone of lakes and ponds represents an important contribution to current knowledge of freshwater biodiversity. Representatives of this family make up a significant fraction of species richness of the invertebrate communities in most water bodies in temperate and tropical regions. Even though chydorids are known to occur in high densities in certain Brazilian water bodies, constituting a significant part of the biomass and secondary productivity of the aquatic communities, scientific records of these anomopods with identification to species level are rare. Two genera of Chydoridae are of outstanding importance: Chydorus, with around 30 species, widely distributed, some of which are among the commonest anomopods, and Pseudochydorus, with only one cosmopolitan species, globosus (Smirnov, 1996).

In a previous study, Elmoor-Loureiro (1997) reported 4 species of Chydorus in São Paulo State, (Ch. eurynotus. Ch. nitidulus, Ch. pubescens and Chydorus sphaericus) and one species of Pseudochydorus, (P. globosus). Although Rocha \& Guntzel (1999) reported seven species of Chydorus (Ch. dentifer, Ch. eurynotus, Ch. pubescens, Ch. nitidilus, Ch, barroisi, Ch. poppei and Ch. sphaericus) two of these in fact belong to the genus Ephemeroporus, E. barroisi and E. tridentatus (Chydorus poppei).

The aim of this study, as an integral part of a project (Zooplankton biodiversity and state of degradation of continental water ecosystems in São Paulo state) within the program BIOTA FAPESP-The Virtual Institute of Biodiversity (www.biota.org.br), was to elaborate an inventory of species of the genera Chydorus and Pseudochydorus and analyze their distribution in the state of São Paulo, Brazil.

\section{Materials and Methods}

In the state of São Paulo, a state law ( $\left.n^{\circ} 7663\right)$ was enacted in December 1991, establishing 22 Water Resource Management Unit (Figure 1), referred to henceforth as UGRHi (Unidades de Gerenciamento dos Recursos Hídricos). The water-bodies within theses units were sampled between September $9^{\text {th }}, 1999$ and August 28 ${ }^{\text {th }}, 2002$, giving 373 samples from 223 water-bodies. The latter comprise small streams, rivers, ponds, lakes, and large reservoirs. In the very small water-bodies, only the littoral zone was sampled, while in bigger ones, both littoral and limnetic zones were sampled.

To obtain qualitative and quantitative data regarding species of Chydoridae cladocerans, both horizontal and vertical hauls were made with a $68 \mu \mathrm{m}$ - mesh plankton net, in the littoral and/or limnetic zones, filtering from 0.1 to $0.3 \mathrm{~m}^{3}$ at a time. Specimens were preserved in $4 \%$ formaldehyde.

Taxonomic identification was performed as described by Megard (1965); the chydorid were dissected and the head shield prepared to make the pores visible. Organisms were identified with the use of specialized keys (Smirnov 1974, 1996, Elmoor-Loureiro, 1997).

\section{Results}

Overall, six species of Chydorus and one of Pseudochydorus were recorded (Figure 2). The commonest and most widely distributed species were Chydorus eurynotus and Chydorus pubescens (Figure 2), with respective constancy indices of $64 \%$ and $68 \%$. Some species were much more restricted geographically, occurring in just one or three UGRHi, as in the case of Chydorus parvireticulatus and Pseudochydorus globosus (Figure 2).

In our inventory, Chydorus parvireticulatus occurred only in the Marreco pond (UGRHi Aguapeí), a small shallow highly eutrophic lake with dense stands of macrophytes.
Pseudochydorus globosus displayed a restricted distribution, also occurring in Marreco Pond (UGRHi Aguapeí), and in two other water-bodies located in the Alto and Baixo Tietê UGRHi.

Among the 22 units studied, the only one, in which no species of Chydorus or Pseudochydorus were recorded, was the Baixada Santista.

\section{Discussion}

The water-bodies under study ranged from oligotrophic to eutrophic, varying widely in their $\mathrm{pH}$, electrical conductivity and concentration of dissolved oxygen and nutrients (Arantes Junior et al. 2001). There was also a great variation in size, from very small and shallow bodies of water to very large reservoirs.

Chydorus eurynotus and Chydorus pubescens which in the present work were the most widely distributed species, are also those among the genus Chydorus the most widely distributed in Brazil (ElmoorLoreiro 1997) occurring since Pará state down to Rio Grande do Sul. The occurrence of Chydorus parvireticulatus is the first record for São Paulo State. This species has been recorded previously in Brazil and Argentina, but until now, Brazilian occurrences were restricted to the states of Amazonas and Pará, in the north. Specimens previously recorded as Chydorus faviformis (Montu \& Gloeden 1986) were later identified as C. parvireticulatus (Elmoor-Loureiro 1997).

In an earlier survey of cladocerans in São Paulo State (Rocha \& Guntzel 1999), a total of 18 species of the subfamily Chydorinae were recorded, among which seven belong to genus Chydorus. Similarly, seven species of Chydorus were recorded in the present study, but there are differences between the new inventory and the former survey. The current list does not include Chydorus barroisi, as this species was recently allocated to the genus Ephemeroporus (Elmoor-Loureiro 1997).

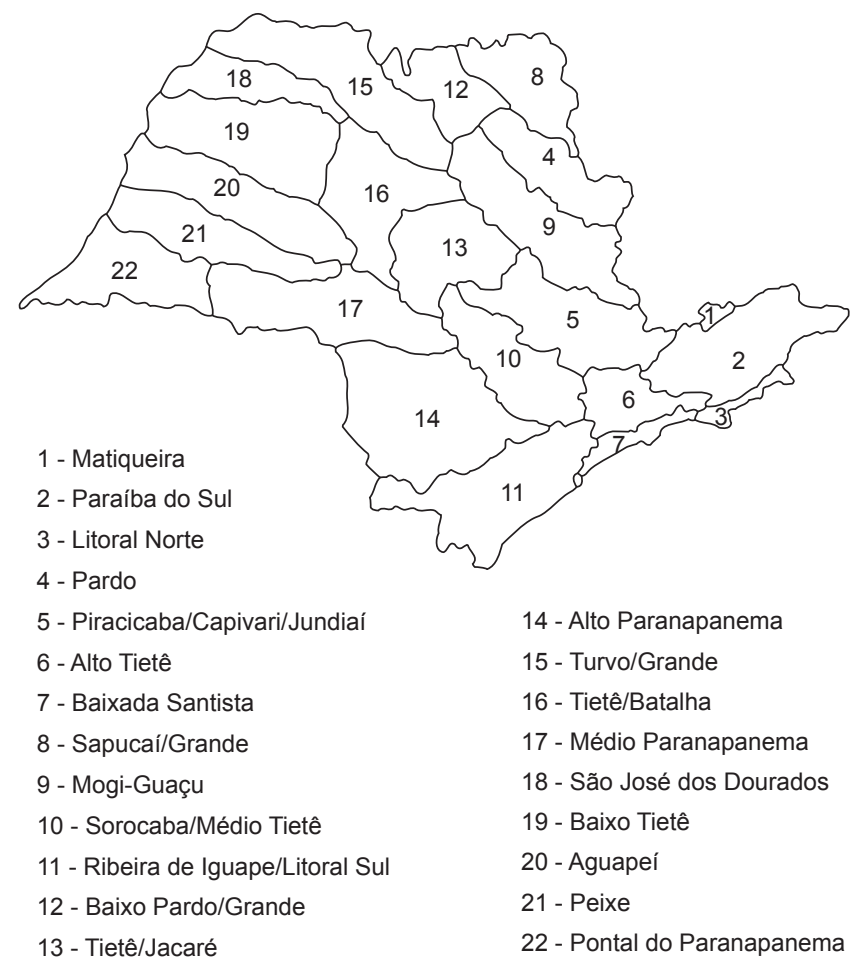

Figure 1. Map of São Paulo State showing the 22 Water Resources Management Units. Source: http://www.biota.org.br.

Figura 1. Mapa do estado de São Paulo mostrando as 22 Unidades de Gerenciamento dos Recursos Hídricos (UGRHi). Fonte: http://www.biota. org.br 

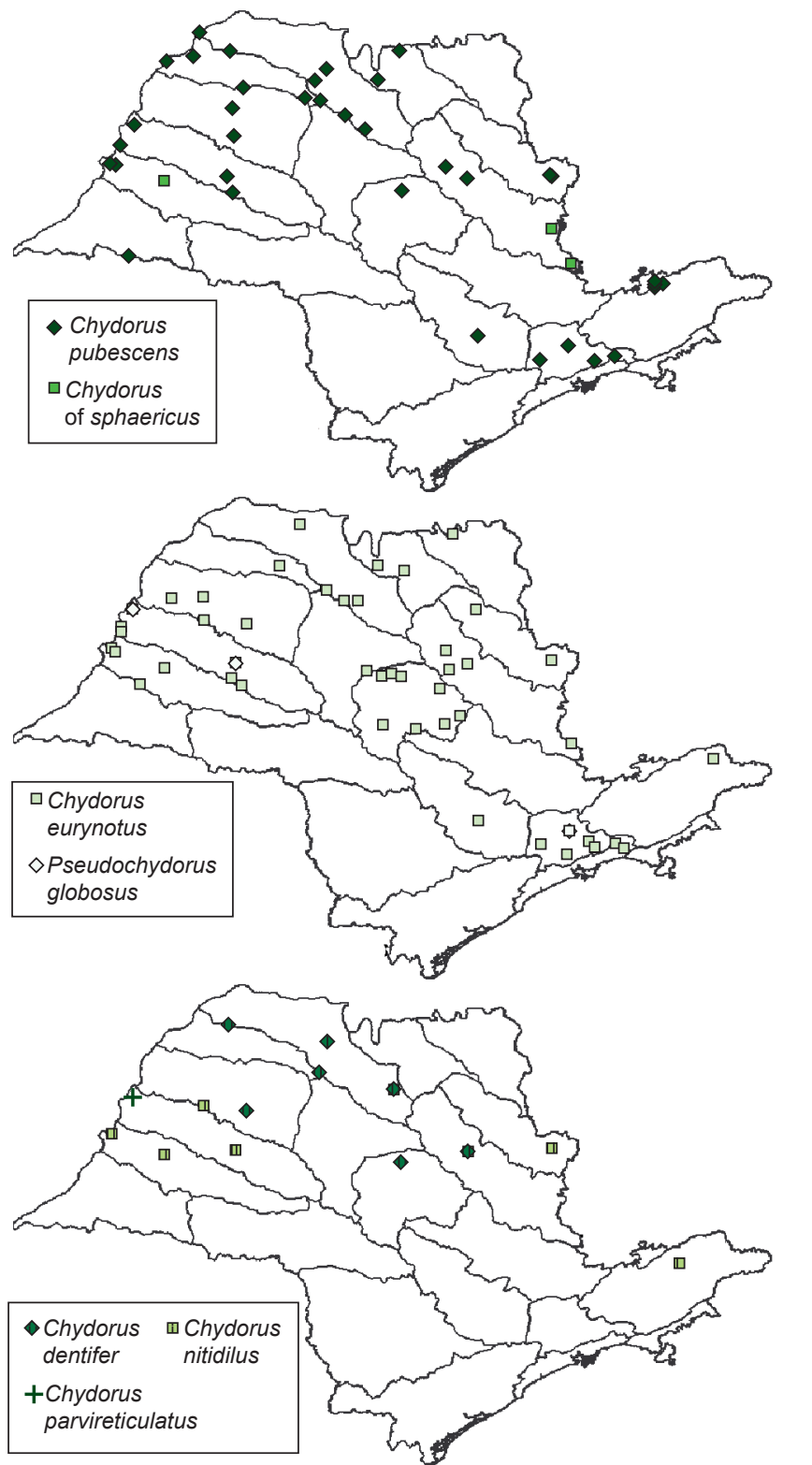

Figure 2. Distribution map of Chydorus and Pseudochydorus species in the Water Resources Management Units of São Paulo State.

Figura 2. Mapa da distribuição das espécies de Chydorus e Pseudochydorus nas Unidades de Gerenciamento dos Recursos Hídricos (UGRHi) do estado de São Paulo.

On the other hand, in the former study, the genus Pseudochydorus was not recorded, although Pseudochydorus globosus had been recorded on previous occasions in the states of Pará (Robertson 1980), Minas Gerais (Santos 1980), and São Paulo (Bergamin 1940, Barbosa \& MatsumuraTundisi 1984). Smirnov (1996) described $P$. globosus as a cosmopolitan species and reported its association with aquatic vegetation; it has been reported to feed mainly on dead cladocerans (Fryer 1968).

Among the 22 units studied, the Baixada Santista was the only the only one, in which no species of Chydorus or Pseudochydorus were recorded, was the Baixada Santista. This observation may be related to the rather small number of lentic water-bodies in the Baixada Santista or the physical and chemical characteristics, trophic degree, etc, of the water sampled in this Atlantic coastal plain; these aspects were not analyzed in this study. In the units where Chydorus displayed low species richness, the water bodies were predominantly large reservoirs with a low abundance of macrophytes. Detailed studies involving the identification of the fauna associated with macrophytes are required, in order to establish the substrate preferences of Chydoridae species and for the ecological interpretation of the distribution patterns here observed. Chydorus sphaericus records in Brazil are doubtful and recent authors believe it could be a species complex. Smirnov (1996) on its account on Chydorinae does not report this species for South America. Considering that this species was recorded in Brazilian freshwaters many times in the past (Elmoor-Loureiro 1997, Rocha \& Guntzel 1999) the matter will deserve further consideration.

\section{Conclusions}

Most of the Chydorus species were found to be widely distributed in the State of São Paulo. The occurrence of C. parvireticulatus is the first record of this species in the state; its geographical distribution is very restricted as this species was found in just one of the 223 water bodies that were sampled.

\section{Acknowledgments}

To São Paulo State Research Funding Agency, FAPESP (Fundação de Amparo a Pesquisa do Estado de São Paulo) for financial support.

\section{References}

ARANTES JUNIOR, J.D., TUNDISI, J.G., MATSUMURA-TUNDISI, T. 2001. Estudo da eutrofização em 12 Unidades Hidrográficas do Estado de São Paulo através da análise de componentes principais. In: II Simpósio do Programa Biota-Fapesp, FAPESP, Águas de São Pedro.

BARBOSA, P.M.M. \& MATSUMURA-TUNDISI, T. 1984. Consumption of zooplanktonic organisms by Astyanax fasciatus Curvier, 1818 (Osteichthyes, Characidae) in Lobo (Broa) Reservoir, São Carlos, SP, Brazil, Hydrobiologia. 113(1):171-182.

BERGAMIN, F. 1940. Os Cladocera 4. Revta Ind. Anim. 3(1):98-101.

ELMOOR-LOUREIRO, L.M.A. 1997. Manual de identificação de cladóceros límnicos do Brasil. Universa, Brasília.

FRYER, G. 1968. Evolution and adaptive radiation in the Chydoridae (Crustacea: Cladocera): a study in comparative functional morphology and ecology. Phil. Trans. Soc. Lond. ser:B, Biol. Sci. 254:221-385.

MEGARD, R. 1965. A chemical technique for disarticulating the exoskeletons of Chydorid Cladocera. Crustaceana 9:208-211.

MONTU, M. \& GLOEDEN, I. M. 1986. Atlas dos Cladocera e Copepoda (Crustacea) do estuário da Lagoa dos Patos (Rio Grande do Sul, Brasil). Nerítica 1(2):1-134.

ROBERTSON, A.L. 1980. Composição, abundância e distribuição de Cladocera (Crustacea) na região de água livre da represa de CuruáUma, PA. Dissertação de Mestrado, Instituto Nacional de Pesquisas da Amazônia, Manaus, AM.

ROCHA, O. \& GÜNTZEL, A.M. 1999. Crustáceos branquiópodos. In: Ismael, D; Valenti, W.C.; Matsumura-Tundisi, T.; Rocha, O. Biodiversidade do estado de São Paulo, Brasil. Invertebrados de Água doce- FAPESP, 4:107-120

SANTOS, L. C. 1980. Estudo das populações de Cladocera em cinco lagos naturais (Parque Florestal do Rio Doce- MG), que se encontram em diferentes estágios de evolução. Dissertação de Mestrado, Universidade Federal de São Carlos, São Carlos, SP.

SMIRNOV, N.N. 1974. Fauna of the U.S.S.R. Crustacea. Chydoridae, v. 1, n. 2. Israel Program for Scientific Translations. Jerusalem.

SMIRNOV, N.N. 1996. Cladocera: the Chydorinae and Sayciinae (Chydoridae) of the World. Guides to the identification of the microinvertebrates of the continental waters of the world. SPB Academic Publishing. Netherlands. 